IRA-International Journal of Education \& Multidisciplinary Studies

ISSN 2455-2526; Vol.12, Issue 02 (August, 2018)

Pg. no. 48-53.

Institute of Research Advances

http://research-advances.org/index.php/IJEMS

\title{
How Instructors Teach and How Students Achieve?
}

\section{Shwu-Huey Wang}

Department of Innovative Design and Entrepreneurship Management, Far East University, Taiwan.

Type of Review: Peer Reviewed.

DOl: http://dx.doi.org/10.21013/jems.v12.n2.p3

\section{How to cite this paper:}

Wang, S. (2018). How Instructors Teach and How Students Achieve? IRA International Journal of Education and Multidisciplinary Studies (ISSN 2455-2526), 12(2), 48-53.doi: http://dx.doi.org/10.21013/jems.v12.n2.p3

(c) Institute of Research Advances.

\section{(cc) EY-NC}

This work is licensed under a Creative Commons Attribution-Non Commercial 4.0 International License subject to proper citation to the publication source of the work.

Disclaimer: The scholarly papers as reviewed and published by the Institute of Research Advances (IRA) are the views and opinions of their respective authors and are not the views or opinions of the IRA. The IRA disclaims of any harm or loss caused due to the published content to any party.

Institute of Research Advances is an institutional publisher member of Publishers Inter Linking Association Inc. (PILA-CrossRef), USA. The institute is an institutional signatory to the Budapest Open Access Initiative. Hungary advocating the open access of scientific and scholarly knowledge. The Institute is a registered content provider under Open Access Initiative Protocol for Metadata Harvesting (OA/-PMH).

The journal is indexed \& included in WorldCat Discovery Service (USA), CrossRef Metadata Search (USA), WorldCat (USA), OCLC (USA), Open J-Gate (India), EZB (Germany) Scilit (Switzerland), Airiti (China), Bielefeld Academic Search Engine (BASE) of Bielefeld University, Germany, PKP Index of Simon Fraser University, Canada. 


\begin{abstract}
The issue of how to increase student's academic performance has been one of the most concerns of educators and researchers for many decades. Instructors may be the most influential ones on students' learning for students need to be properly navigated in the process of learning. Meanwhile, how instructors present their class lecture will also impact on learning outcome. The purpose of the study is to provide a perception framework for the study of teaching way, conversation ability and students' academic achievements. The related works are reviewed.
\end{abstract}

Keywords: Teaching way, Instructor's conversation ability, Academic achievements

\title{
Introduction
}

For learners are always inexperienced, they have to be navigated in the learning process, instructors are probably the most influential people in the process, the fact that instructors play a key role in the learning process may be acknowledged by all of the educators. Past research ( Griffith, Wilson, Haist \& Ramsbottom-Lucier, 1997;1998 ) reported that students could learn more in the programme from a well-experienced instructor. The communicative effect in the class usually decides the majority of learning, however, for students in the same class may come from different settings and with uneven academic abilities, it becomes clearly important for instructors to find out a typical method to be helpful and meaningful on their learning, meanwhile, how the instructor presents his/her way to communicate with students, which way is the best way for learners, what style is the most preferable by students and will be contributable to their academic achievements remains worthy to be understand. On the other hand, conversation ability is the basic skill for instructors to perform their teaching function in the class, the way they interpret contents of knowledge and how they present the knowledge structure may all be influential on student's academic performance. Therefore, the purpose of the study is to provide a conceptual framework to interpret the relationship between teaching ways, instructor's conversation ability and student's academic achievements.

\section{Theoretical Context}

\section{How to Teach?}

The ways that an instructor interacts with students in the classroom have received a great attention in the past years, for weather it is effective on learning may be reflected through the students' academic achievements. Teaching ways refers to instructor's perspectives on teaching and learning and the communicative ways in the classroom they preferred ( Opdenakker \& Damme, 2006 ) . People would like to ask: "Why do we need to study teaching way?" Actually, there are many key factors we need to concern about in terms of an instructor, for example: personality, experiences, attitudes, beliefs, backgrounds or behaviors. However, by understanding what are the most effective ways for students' learning, instructors can easily enhance the efficiency of learning and class communication. Therefore, it is important to understand teaching style as educators can ensure what the best learning experiences are so that they can help students to improve learning effect. Additionally, past research has indicated that teaching ways are helpful to explain the impacts of instructors on student academic achievements (Aitkin \& Zuzovsky, 1994; Ebmeier \& Good, 1979), meanwhile, teaching ways can also make 
great differences on student learning (Centra \& Potter, 1980; McDaniel, 1981; Wentzel, 2002).

The objective of education is to facilitate learning. Educators do realize that students are all different and with various preferences and ways of learning, hence, it is believed that even different learning ways may be satisfied by properly using teaching skills and strategies in the learning process (Seaman and Fellenz, 1990). Teaching way is the instructor's specific way, which is ensured by a certain internal belief and presented from a distinguished style in the class. Teaching style is not just a method but something more important and correlates to the whole teaching-learning process. On the other hand, teaching style is not an excuse for poor teaching quality, improper classroom behaviors or emotionally conducted teaching methods (Heimlich, \& Norland, 2002).

Past research indicated that instructors' perspectives toward the essence of teaching and student learning will greatly influence teaching methods and practices in classes (Boulton-Lewis, Smith, McCrindle, Burnett, \& Campbell, 2000; Prawat, 1992; Waeytens, Lens, \& Vandenberghe, 2002). Researchers developed scales for various purposes of use; however, the most thoroughly refined model may be Mosston's Spectrum of Teaching Ways, which has been in continuous use for many years. The current version of the spectrum (Kulinna \& Cothran, 2003) includes 11 different teaching ways: (a) Command (b) Practice (c) Reciprocal (d) Self check (e) Inclusion (f) Guided discovery (g) Convergent discovery (h) Divergent production (i) Learner's Individual designed program $(j)$ Learner initiated $(k)$ Self-teaching. (Please refer to Appendix for short description of each style). Cothran, Kulinna and Ward (2000) revised the scale by using the following questions after each teaching scenario: (a)"I had a physical education instructor that taught this way"; (b)"I think this way of teaching would make class fun"; (c)"I think this way of teaching would help students learn skills and concepts"; (d)" I think this way of teaching would motivate students to learn". The research suggested that it is instructors' obligation to help students develop independent thinking skill with clearly stated steps in the process of learning. The more the instructors understand the student's perceptions of various of teaching ways, the more they can be well-prepared to provide effective and helpful instructional method to improve student's academic performance.

\section{Instructor's Conversation Ability}

The efficiency of communication may be the most concerned topic by businessmen in the business field. Communication efficiency reflects the speed of achieving tasks, goals or objectives; therefore, the communication competency may be regarded as the performance of a sales representative. Previous research (Cushman and Craig, 1976) argued that a communicator's competence may be presented by way of individual ability in the areas of listening and negotiating.

Similarly, a instructor's conversation ability in the class may also be thought as a key factor to influence students' academic performance. Communicative competence refers to instructor's ability to participate in the discussion about what has to be maintained and what has to be changed in the process of learning. A communicatively competent instructor can fully interpret the contents of the problems or regulations instead of merely regulating them as given (Rogers, Noblit \& Ferrell, 1990). Communicative competence enables one with the "ability to read or decode the taken-for-granted assumptions and conceptual categories that underlie the individual's world of experience" (Bowers, 1984, p2). In other words, instructors have to transform the 
knowledge into orally understandable words for students to take in the class to implement the objective of learning. For students in the class may have different backgrounds and performances, how instructors can help them by adopting a suitable way to facilitate learning seems to be even more important. Meanwhile, students in modern society can easily receive knowledge resources from assorted kinds of channels, how instructors communicative with them and persuade them turns out to be a critical issue apparently.

"In the naturally processed communication, information could consist of something conceptual, something social, something cultural, something affective, or even something psychological "(Canale, 1983, p. 4). Additionally, not all the participants engaged in the communication have similar knowledge, personality or background to fulfill the task. Therefore, the consequence of the communication may be unpredictable. In the case of class communication, instructors have to face students with different levels of knowledge or comprehensive ability; they need to present conceptual structure hierarchically for students' understanding. Whether the instructor's communicative competence make sense will play a key role in the point.

\section{Conceptual Framework}

The above two propositions lead to a research model of the relationship of teaching ways, instructor's conversation ability and student's academic achievements.

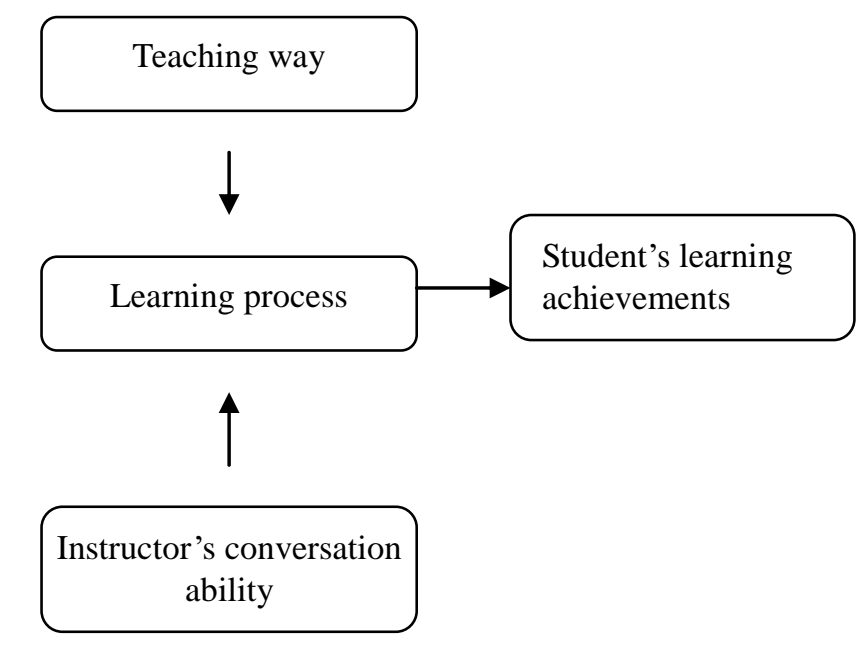

Fig. 1. Conceptual model of teaching style and instructor's communicative on student's academic achievements

\section{Limitations}

Based on the research stated above (Aitkin \& Zuzovsky, 1994; Ebmeier \& Good, 1979), teaching way is a critical factor to explain student's academic achievements. On the other hand, weather instructor's conversation ability is helpful and can be easily taken by students also accounts great part for student's learning. However, the two stated factors (teaching ways and instructor's conversation ability) are concerning about instructor-student interaction in the classroom. It is acknowledged that the factors that impacts on student's academic 
achievements are numerous, for example: student's learning ways, student's motivation on learning, student's personality and value on learning, family background and parents' attitude toward learning...etc. In other words, factors come from internal or external may both be the crucial reasons to influence learning. Though the dimension of instructor-student interaction is regarded as truly important, it reflects only part of the real thing of student's learning.

\section{Conclusions}

No matter what teaching ways instructors prefer to adopt or whether the instructor is with communicative competence, as stated above, the objective of education is to facilitate learning, we would like to maintain that if only the ways are accepted or easy to be taken by the students, they are effective ways, in other words, they will have positive effects on student's academic achievements. As the macro environment is changing drastically in the recent years, instructors or school authority should have noticed that even the external environment is keeping change, the essence of education remains the same. Instructors are devoting themselves in cultivating specialized manpower for future competition. An experienced instructor may adopt different teaching ways based on his/her experiences or adjust the communicative ways by evaluating the interactions between instructor and student in the classroom.

On the other hand, living in an era of diversified information, students may learn knowledge from more various kinds of channels than that of before. Though in-classroom learning remains the most effective and direct way to acquire knowledge, it's not the only way to learn. Therefore, instructors should adopt more flexible ways by understanding and evaluating the current situation so that it would be more helpful on students' learning. In short, educators should try to communicate with students through sequential and organized ways to create a win-win situation.

\section{References}

[1]. Aitkin, M., \& Zuzovsky, R. (1994). Multilevel interaction models and their use in the analysis of large-scale school effectiveness studies. School Effectiveness and School Improvement, 5, 45-73.

[2]. Boulton-Lewis, G. M., Smith, D. J. H., McCrindle, A. R., Burnett, P. C., \& Campbell, K.,J. (2000). Secondary instructors' conceptions of teaching and learning. Learning and Instruction, 11, 35 - 51.

[3]. Bowers, C. (1984). The promise of theory. New York: Longman.

[4]. Canale, M. (1983). From communicative competence to communicative language pedagogy. In: Jack C. Richards \& Richard W. Schmidt. (Eds.), Language and communication. London: Longman.

[5]. Centra, J. A., \& Potter, D.A. (1980). School and instructor effects: An interrelational model. Review of Educational Research, 50(2), 273-291.

[6]. Cothran, D., Kulinna, P.H. \& Ward, E. (2000). Students' experiences with and perceptions of teaching ways. The Journal of Research and Development in Education, 33(5), 93-103.

[7]. Cushman, D. P., \& Craig, R. T. (1976). Communication systems: Interpersonal implications. In G. R. Miller (Ed.), Exploration in interpersonal communication (pp. 37-58). Beverly Hills, CA: Sage. 
[8]. Ebmeier, H., \& Good, T. L. (1979). The effects of instructing instructors about good teaching on the mathematics achievement of fourth grade students. American Educational Research Journal, 16(1), 1-16.

[9]. Griffith CH, Wilson JF, Haist SA, Ramsbottom-Lucier MT. Do students who work for better housestaff in their medicine clerkships learn more? Acad Med 1998;73 (Suppl):S57-9.

[10]. Griffith CH, Wilson JF, Haist SA, Ramsbottom-Lucier MT. Relationships of how well attending physicians teach to their students' performances and residency choices. Acad Med 1997;72 (Suppl):S118-20.

[11]. Heimlich, Joe E. \& Norland, Emmalou (2002). Teaching style: Where are we now? New Directions for Adult and Continuing Education, No. 93, Spring, 17-25.

[12]. Kulinna, P. H., \& Cothran, D. (2003). Physical education instructors' self-reported use and perceptions of various teaching ways. Learning and Instruction, 13, $597-609$.

[13]. McDaniel, T. R. (1981). Criticism, research and reform in contemporary education: The search for "significant differences". Contemporary Education, 53(1), 6-8.

[14]. Opdenakker, Marie-Christine \& Damme , Jan Van (2006). Instructor characteristics and teaching ways as effectiveness enhancing factors of classroom practice. Teaching and Instructor Education, 22, 1-21.

[15]. Prawat, R. S. (1992). Instructors' beliefs about teaching and leaning: a constructivist perspective. American Journal of Education, 100, $354-395$.

[16]. Rogers, D.L., Noblit, G.W. \& Ferrell, P. (1990) Action research as an agent for developing instructors' communicative competence. Theory Into Practice, 29(3), 179-184.

[17]. Seaman, D.F., and Fellenz, R.A. Effective strategies for teaching adults. Columbus, Ohio: Merrill, 1990.

[18]. Waeytens, K., Lens, W., \& Vandenberghe, R. (2002). 'Learning to learn': Instructors' conceptions of their supporting role. Learning and Instruction, 12, $305-322$.

[19]. Wentzel, K. R. (2002). Are effective instructors like good parents? Teaching ways and student adjustment in early adolescence. Child Development, 73, 287-301. 